\title{
DEVICE FOR PRODUCTION OF PLASTIC FILAMENT FOR 3D PRINTER
}

\section{J. Molnár, P. Hrabovský}

Technical University of Košice

Letná, 9, 04200 Košice, Slovak Republic. E-mail: jan.molnar@tuke.sk, peter.hrabovsky@tuke.sk

Purpose. Development the low-cost device for production plastic filament for 3D printing using plastic waste. Originality. The paper deals with the research on surveys for development of a low-cost sample 3D plastic filament production machine using modern automatic control equipment. Methodology. The paper proposes one of the possibilities for development low-cost 3D plastic filament production machine controlled by industrial PLC and equipped with human-machine interface. Authors described whole development process starting from description of machine operation principles, control software development and testing process, and finishing with HMI software development and testing and also experimental verification of derived results. Results. Basic concept of the device was defined. The control program was developed using SIMATIC STEP 7 environment from SIEMENS. The HMI interface for filament extruder was created using SIMATIC WinCC software. Tests of the interconnection of the control software developed for PLC control program and the HMI interface was showed reliable results. After the project implementation, we tested the system's functionality. We can say the system works correctly. After appropriate modification and configuration, it could be applied to the physical device for which the project was designed. Practical value. As result, it will be developed low-cost sample of 3D-printer's plastic filament production machine which allowed us to supply 3D printers with filaments for self-consuming needs. Developed device will allow us to produce different kinds of materials such as composite conductive materials and others. References 10, figures 21.

Key words: control program, Human Machine Interface, plastic filament, Programmable Logical Controller.

\section{ПРИСТРІЙ З ВИГОТОВЛЕННЯ ПЛАСТИКОВИХ НИТОК ДЛЯ ЗD ПРИНТЕРІВ}

\section{Я. Мольнар, П. Грабовський}

Технічний університет Кошице

вул. Лєтня, 9, м. Кошице, 04200, Словаччина. E-mail: jan.molnar@tuke.sk, peter.hrabovsky@tuke.sk

Метою роботи $є$ розробка малобюджетного пристрою з виробництва пластикових ниток для 3D принтеру 3 пластикових відходів. У статті наведено результати досліджень щодо розробки малобюджетного екземпляру пристрою 3 виробництва пластикових ниток для 3D принтеру з використанням сучасної елементної бази пристроїв систем автоматизації. У статті пропонується використати одну з можливостей розробки малобюджетного пристрою з виробництва пластикових ниток для 3D принтеру під керуванням промислового ПЛК, обладнаного засобами людино-машинного інтерфейсу. Наведено опис усього виробничого процесу, починаючи 3 опису принципів роботи пристрою, процесу розробки та тестування керуючого програмного забезпечення, та закінчуючи розробкою людино-машинного інтерфейсу, тестуванням та експериментальною перевіркою розроблених програмних рішень та отриманих результатів. Було визначено основні концепції побудови пристрою. Керуючу програму було розроблено з використанням середовища SIMATIC STEP 7 фірми SIEMENS. Людино-машинний інтерфейс пристрою було розроблено за допомогою програмного забезпечення SIMATIC WinCC. Тестування взаємодії керуючого програмного забезпечення ПЛК та людино-машинного інтерфейсу показало задовільні результати. Після реалізації проекту було перевірено функціональність системи, що також показало задовільні результати. Після відповідної модифікації та конфігурування, розроблені програмні та технічні рішення можуть бути застосовані у реальному фізичному пристрої, задля якого і було створено проект. У кінцевому результаті, буде розроблено малобюджетний примірник пристрою з виробництва пластикових ниток для 3D принтеру, який дозволить постачати витратний матеріал для 3D принтерів, що зможе забезпечити власні потреби. Розроблений пристрій дозволить виробляти різні види матеріалів, такі як композитні провідні матеріали та інші.

Ключові слова: керуюча програма, людино-машинний інтерфейс, пластикові нитки, програмований логічний контролер.

PROBLEM STATEMENT. A machine for producing a plastic filament also called filament extruder is a device that converts crushed plastic (pellets) into a plastic fiber. Extruders are the reason you should stop throw up your old or failed prints to waste. They use shredded plastic or pellets, which are much cheaper compared to comparable amounts of the filament. Inventables CEO Zach Kaplan claims that the cost savings can be as much as $90 \%$ ! That is why this machine is very welcome today [2].

The principle of plastic fiber production is simple:
Plastic pieces push through the heated area, where they are melted, and the liquid plastic is extruded through the nozzle as well as the strand of filament. The idea of having your own production line and being independent of commercially available materials is a great dream for every 3D printer user. On the market, commercial solutions are offered in the form of large production lines designed for bulk production. Such a production line can be seen in Figure 1. However, such a large production line is not required for our use. We do not plan serial production of strings and their subsequent 
sale. The equipment we need for our use will be serve for self-consuming.

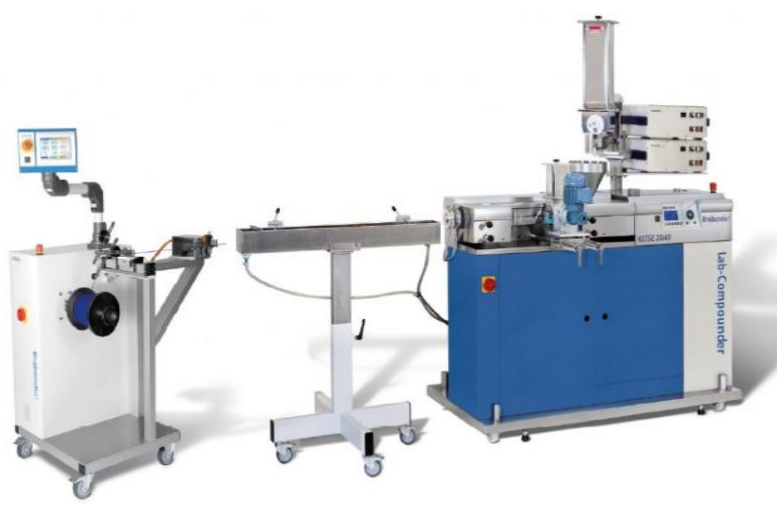

Figure 1 - Commercial manufactured line for production of filament for 3D printers [3]

The main part of the extruder is a barrel containing the Archimedean screw. The screw is mounted in the cylinder-shaped housing. One end is connected to the electric motor and the other is at near the nozzle. The electric motor will transport pellets trough barrel towards the heater. The electric motor will transport material through the barrel towards the heater. Pellets are gravity-fed continuously from a hopper. As the motor is continuously driving the Archimedean screw, the pellets are pushed into the heater. The thermoplastic pellets will soften and melt because of the heat and are then pushed mechanically through a die with a specific diameter and shape. Pushing the soft thermoplastic pellets through the die will cause it to form a continuous filament strand with the diameter of the die $(1.75 \mathrm{~mm}$ or $3 \mathrm{~mm})$. This process is called extrusion, hence the term "extruder". In the Figure 2 we can see the process production of plastic filament $[4,5]$.

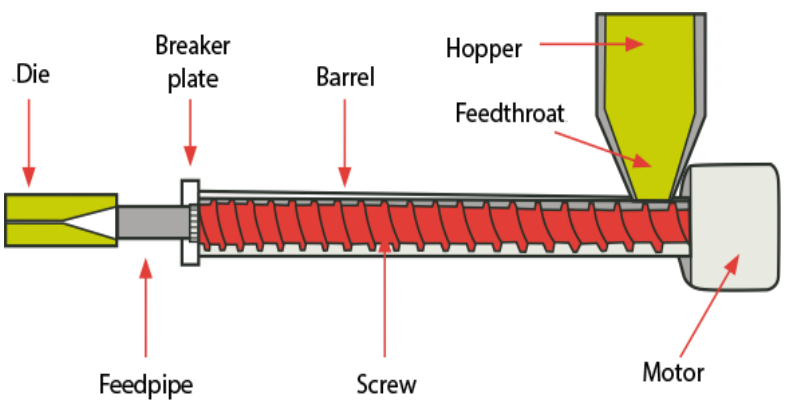

Figure 2 - The process production of plastic filament extrusion [5]

Programmable logic controller

A programmable logic controller (PLC) or programmable controller is an industrial digital computer which has been ruggedized and adapted to the control of manufacturing processes, such as assembly lines, or robotic devices, or any activity that requires high reliability control and ease of programming and process fault diagnosis $[1,6]$.
The most used software for programming PLC is SIMATIC STEP 7 from SIEMENS. There are three forms of programming in standard software SIMATIC STEP 7: STL - (Statement List.), FBD - (Function Block Diagram) and LAD (Ladder Logic). These languages, you can switch from one language to another with virtually no restrictions, and choose the most suitable language for a particular block that is currently programmed $[1,6]$.

\section{STL - Statement List}

List command is the principal means for the creation of the program, i.e., this is the lowest level of PLC programming methods, this type of language is supported by all PLCs. Using the list of instructions can use all the instructions that are available in the CPU, the graphic displays that option may be limited $[1,6]$.

FBD - Function Block Diagram

This language is used for programming flowcharts. The program consists of the blocks with the respective functions and recalls drawing a scheme of integrated circuits $[1,6]$.

\section{LAD - Ladder Logic}

It enables programming using schematic diagrams, which show based on the principle of drawing electrical diagrams in liner design. The logic of writing from left to right, so the left side of the input signals, the output signals of the right. We can see LAD programming editor in the Figure $3[1,6]$.

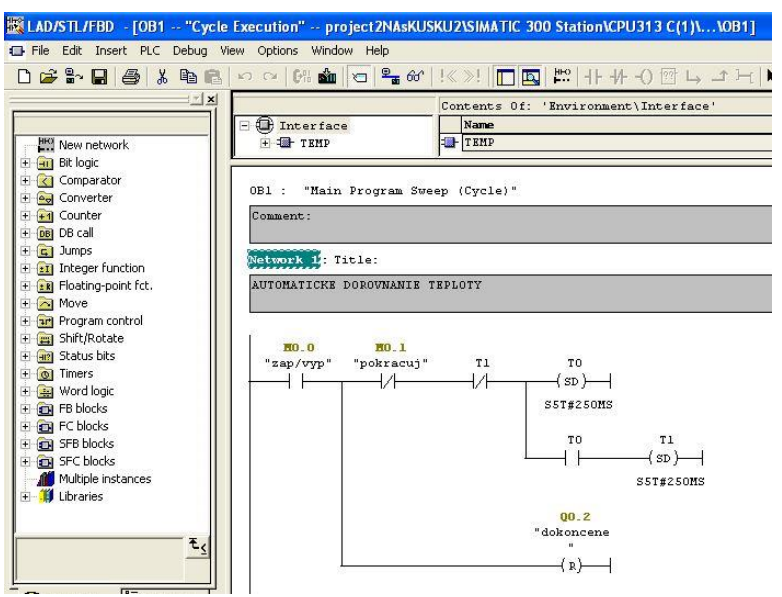

Figure 3 - LAD programming editor

\section{PLC control program}

This chapter describes the functionality of individual processes running in the PLC system. The device control program is programmed in the SIMATIC STEP 7 - Micro / WIN development environment. The program is written for SIMATIC 300 Station, specifically for CPU313C hardware. Ladder Logic (LAD) diagram was used to create the program. The source code for this management program will not be published in the article. Figure 4 shows the list of used inputs and outputs addresses in the PLC control program. 


\begin{tabular}{|c|c|c|c|c|c|c|}
\hline \multirow[b]{2}{*}{4} & \multirow{2}{*}{ Status } & \multirow{2}{*}{$\begin{array}{l}\text { Symbol } \\
\text { chyba nizka teplota }\end{array}$} & \multicolumn{2}{|c|}{ Address } & \multirow{2}{*}{$\begin{array}{l}\text { Data type } \\
\mathrm{BOOL}\end{array}$} & \multirow{2}{*}{ Comment } \\
\hline & & & & 20.2 & & \\
\hline 2 & & chyba prehriatie & M & 20.4 & $\mathrm{BOOL}$ & \\
\hline 3 & & chyba wyprazdnitZas... & M & 20.1 & $\mathrm{BOOL}$ & \\
\hline 4 & & chyba wyska teplota & M & 20.3 & BOOL & \\
\hline 5 & & Cycle Execution & $\mathrm{OB}$ & 1 & $\mathrm{OB} \quad 1$ & \\
\hline 6 & & dokoncene & $Q$ & 0.2 & $\mathrm{BOOL}$ & \\
\hline 7 & & doplnZasobnik & M & 0.6 & BOOL & \\
\hline 8 & & emergency stop & M & 0.2 & BOOL & \\
\hline 9 & & emergency stop output & Q & 0.1 & BOOL & \\
\hline 10 & & hmotnostNaw Yyrobku & MN & 6 & WORD & \\
\hline 11 & & mnozstvo plastu v zas. & QW & 5 & WORD & \\
\hline 12 & & navyjanie & Q & 0.3 & BOOL & \\
\hline 13 & & neprechodna tryska & Q & 0.6 & BOOL & \\
\hline 14 & & nizka teplota & Q & 1.1 & BOOL & \\
\hline 15 & & odlievanie & Q & 9.1 & BOOL & \\
\hline 16 & & ohrev & Q & 0.5 & $\mathrm{BOOL}$ & \\
\hline 17 & & $\mathrm{pb}$ emergency & $\mathrm{M}$ & 20.7 & BOOL & \\
\hline 18 & & pla/abs & $\mathrm{M}$ & 0.4 & $\mathrm{BOOL}$ & \\
\hline 19 & & plna cievka & $\mathrm{Q}$ & 1.2 & BOOL & \\
\hline 20 & & pocet cievokMyrobkov & MW & 4 & WORD & \\
\hline 21 & & pocet navynutych cie... & QW & 7 & WORD & \\
\hline 22 & & pokracuj & M & 0.1 & BOOL & \\
\hline 23 & & prazdny zasobnik & $Q$ & 1.3 & BOOL & \\
\hline 24 & & priehriata tryska & Q & 0.7 & BOOL & \\
\hline 25 & & reset_hmNaWyrobku & M & 8.0 & BOOL & \\
\hline 26 & & sprava & FC & 1 & FC 1 & nizkaTeplota \\
\hline 27 & & teplota trysky & QW & 3 & WORD & \\
\hline 28 & & uvolnenie wyrobku & Q & 9.0 & BOOL & \\
\hline 29 & & v prevadzke $M y p n u t e$ & $Q$ & 0.0 & $\mathrm{BOOL}$ & \\
\hline 30 & & vaha cievky/Myrobku & MW & 2 & WORD & \\
\hline 31 & & vyroba strunyiodlieva... & $\mathrm{M}$ & 0.3 & BOOL & \\
\hline 32 & & vysoka teplota & Q & 1.0 & BOOL & \\
\hline 33 & & vytlacanie & Q & 0.4 & BOOL & \\
\hline 34 & & zapмyp & $\mathrm{M}$ & 0.0 & BOOL & \\
\hline 35 & & zaseknuty odliatok & Q & 9.2 & BOOL & \\
\hline
\end{tabular}

Figure 4 - Table of used input, output and memory cell addresses used in the PLC control program

Processes in the control program

Automated canned Cycle:

Before setting the bit "zap/vyp (M0.0 = 1)", the number of coils or products "počet cievok/výrobkov (MW4)" and the coil or product weight "váha cievky/výrobku (MW2)" must be selected. The settings you make determine the numbers of process cycles and the length of each process. The weight of the coil or product "cievky/výrobku (MW2)" is checked in comparator that compares the "counter C2" value and the desired weight. When it is reached, the number of products produced increases and the cycle is repeated again. The number of coils or products "počet cievok/výrobkov (MW4)" sets "counter C1" to the desired value. After each coil produced, the value stored in "counter $\mathrm{C} 1$ " is decremented. When the "counter $\mathrm{C} 1$ " reaches zero value, the cycle is terminated, production is complete and bit "dokoncene Q0.2" is set to 1 .

Nozzle heating:

The heating and thermostat function are simulated by a flip-flop circuit which increments or decrements the temperature value "counter $\mathrm{C} 0$ ", the nozzle temperature setpoint is set by selecting PLA $\left(230^{\circ} \mathrm{C}\right)$ or ABS $\left(250^{\circ} \mathrm{C}\right)$ plastic.

Extruding plastic out of the nozzle:

Extrusion of the plastic from the heated nozzle will be triggered when the correct nozzle temperature, which is determined by the plastic type, is reached. We can see the nozzle temperatures for material PLA and ABS in Table 1.
Turning on winding:

Winding is activated two seconds after the extrusion starts.

Number of Coils Wound:

It is obtained by subtracting the value of the counter C1 from our set number of coils or products "počet cievok/výrobkov (MW4)". "Counter C1" shows how many coils still need to be made to finish the process.

Heating Indication:

Heating is indicated when the nozzle temperature is rising up.

Alarm temperature indication:

Three temperature states are displayed in the form of alarms. The indication is realized by comparators that compare the nozzle temperature "teplota trysky (QW3)" with the temperatures defined by us for each state. Individual temperatures are set as shown in Table 1.

Table 1 - Indication of nozzle temperatures for materials

\begin{tabular}{|c|c|c|c|c|}
\cline { 2 - 5 } \multicolumn{1}{c|}{} & \multicolumn{4}{c|}{ Nozzle temperature [ $\left.{ }^{\circ} \mathrm{C}\right]$} \\
\hline Material & Low & Working & High & Overheated \\
\hline PLA & $<$ & $225-$ & $236-$ & $>240$ \\
\hline ABS & $<$ & $245-$ & $256-$ & $>260$ \\
\hline
\end{tabular}

The temperature is low:

In this state, the extrusion of the plastic is stopped, the heating is switched on to set the desired nozzle temperature. After reaching the desired temperature, the duty cycle is restored.

The temperature is high:

In this state, plastic extrusion is suspended, the extrusion is suspended until it drops to the working temperature for the plastic used. After reaching the desired temperature, the work cycle is resumed.

Overheated nozzle:

This condition threatens to damage the device, so the Emergency Stop mode is triggered.

Working temperature:

The correct working temperature of the nozzle is considered to be the correct operation of the device and is therefore not classified as an alarm.

Plastic hopper:

The amount of plastic in the hopper "Množstvo plastu v zásobníku (QW5)" can be set to a maximum of 500 grams. Using the "counter C3", we count out the value from the hopper. After reaching Q1.3 $=0$ "prázdny zásobník", the process will stop. By setting the bit "doplň Zásobník (M0.6)" to $\log 1$, add value of 100 to the QW5 value, representing 100 grams of plastic in the hopper. Subsequently, you can reset the paused duty cycle by setting the bit to continue (M0.1) to $\log 0$.

Emergency stop status:

It is executed with a bit "emergency stop (M0.2=1)". After its setting all processes are finished and the device is switched off.

Early termination:

Set the bit "zap/vyp (M0.0)" to $\log 0$ to complete the production process. 
Production stop:

By setting the bit "pokračuj (M0.1)" to $\log 1$ to suspend the production process. After resetting the bit to $\log 0$, production continues from the state it was stopped.

In Figure 5 we can see the environment of the S7 PLCSIM simulator. The figure shows the individual windows showing the selected PLC inputs and outputs. We can use our check box windows to manage our device. The individual windows are related to Figure 4 , where the used addresses of inputs, outputs and memory cells are described.

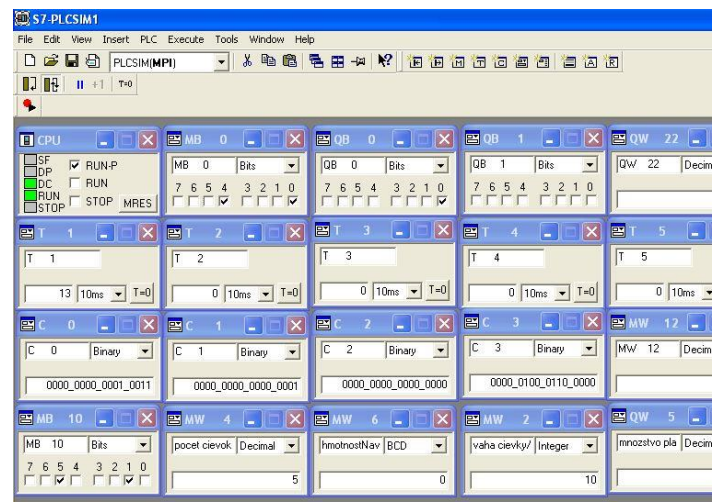

Figure 5 - Environment of S7 PLCSIM simulator

Human Machine Interface

The Human Machine Interface (HMI) interface transmits information from machine to person. Using HMI, we can display and animate data dynamics, send process commands, modify process parameters for production, and showing process error messages (alarms). When creating the HMI environment, it is necessary to emphasis on the ergonomic environment, reliable and safe process operation and, last but not least, the easy and efficient exchange of information between the operator and the managed system. HMIs are usually deployed on Windows-based machines, communicating with programmable logic controllers (PLC) and other industrial controllers. HMI is a device designed to provide a person with insight into the technological process and inform it of process parameters in real time. Furthermore, it should allow a person to change process parameters conveniently. On Figure 6 we can see some HMI displays from SIEMENS. Programs such as Simatic WinCC (TIA Portal), FactoryTalk View Machine Edition, EcoStructure Operator Terminal Expert and others are used to create HMI interfaces $[1,7,8]$.

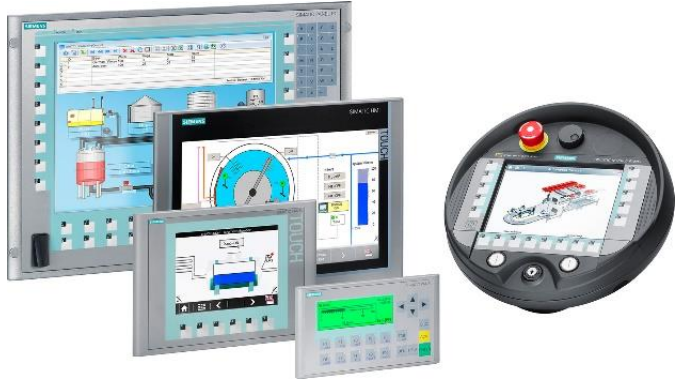

Figure 6 - HMI displays from SIEMENS [9]

\section{Design of HMI}

We used SIMATIC WinCC from SIEMENS to design the HMI interface.

Start screen of HMI

In the Figure 7 you can see the start screen that appears when you run WinCC-Runtime. The screen has 5 buttons. For input or mode selection, it is necessary to authenticate with the button called PRIHLASIT. After pressing the button, the user is prompted to enter the login name (Login $\rightarrow$ Operator) and password (Password -> 123456), and press the OK button to confirm. After logging in, the operator gains access to the choice of two modes, namely, filament production or casting. After pressing one of the modes, the mode is activated and its mode is displayed. The start screen also includes the ODHLASIT button and the UKONCIT button. The button ODLHASIT logs off the operator from the system and then another user could log in. Use the END button to deactivate the entire WinCCRuntime and close the window.

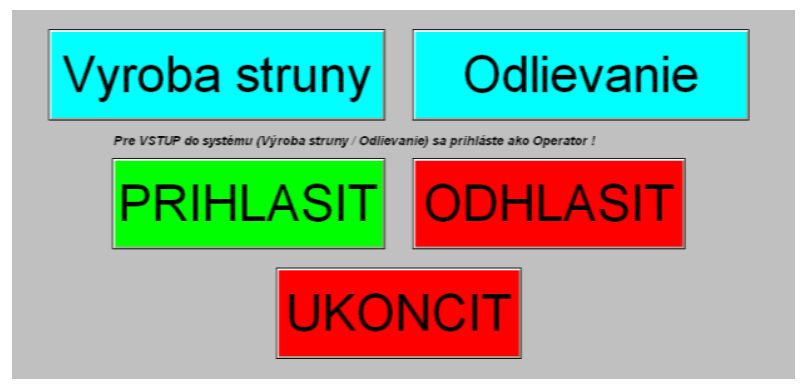

Figure 7 - Start screen of HMI

Screen of production filament

After starting the production of filament mode, the screen that can be seen is shown in fig Figure 8.

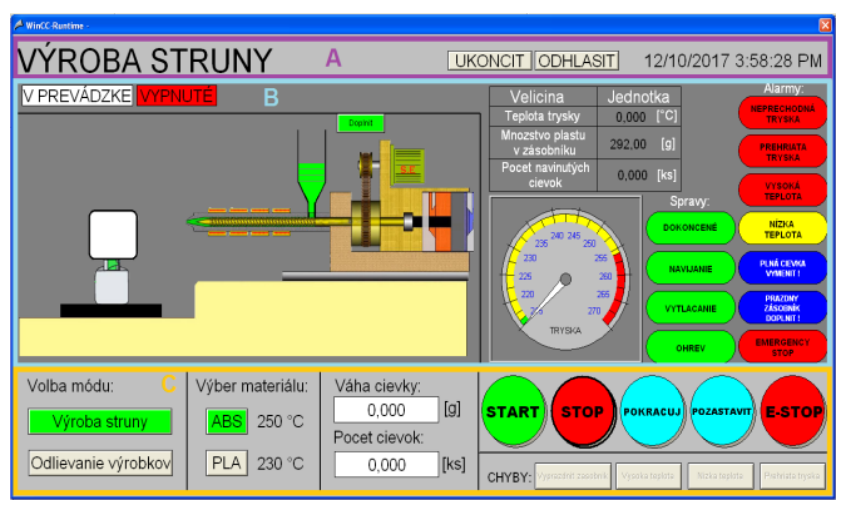

Figure 8 - Production of plastic filament for 3D printer

The HMI screen is divided into the following main parts:

Overview area

On the Figure 9 we can see the overview area of HMI. The name of the production process is located in the left part of this area. Next there are buttons for ending the program UKONCIT and logging out ODHLASIT of the mode. The current time and date are on the right. If you press the button UKONCIT the 
entire program will be turned off. Both buttons can only be pressed if no production process is in progress, otherwise pressing them is systemically prohibited!

\begin{tabular}{lllll}
\hline VÝROBA STRUNY A UKONCIT ODHLAST & $12 / 10 / 2017$ 3:58:28 PM \\
\hline
\end{tabular}

Figure 9 - Overview area

\section{Working area}

On the Figure 10 we can see the working area of HMI. The technological process of production is shown in the left part of this area. Four pictures that show us the individual states of the production of filament are gradually switched over. In the figures, it is possible to see a machine for producing a filament and a coil with a motor on which the produced filament is wound. On the machine there is a hopper on which we can see the current state of the contained amount of plastic. If the tray is empty, the red button Doplnit flashes. Pressing the Doplnit' button once adds 100 grams of plastic and the button stops blinking and turns color to green. The hopper can be fill to a maximum weight of 500 grams of plastic pellets.

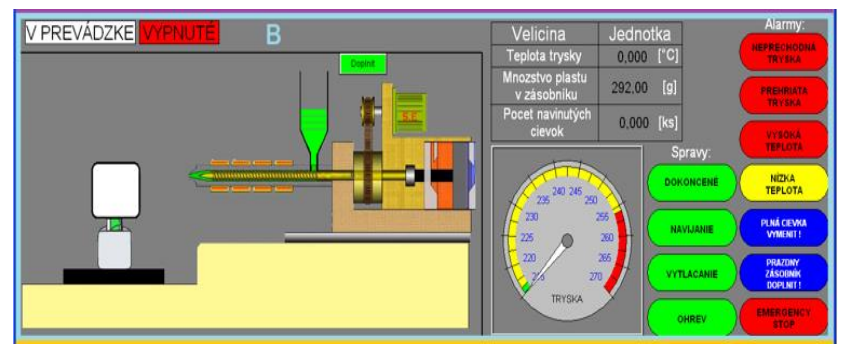

Figure 10 - Working area

In the right of the technological process there is a table that shows the individual quantities and their units as the temperature of the nozzle, the amount of plastic in the container, the number of coils wound. An analog nozzle temperature display called TRYSKA is also located below the table. It displays the temperature according to the values given in the control program for a given type of material, namely ABS or PLA. On the right, there are popups Spravy and Alarmy. Individual pop-ups Spravy and Alarmy show us the states in which the production process of filament is located. The green message OHREV signals the heating of the nozzle to the desired temperature. The green message VYTLACANIE indicates when a filament will flow out from the nozzle. The filament winding process is shown in green message by NAVIJANIE. This process is completed after one coil is winding the filament. When the specified number of coils has been wound up, the status DOKONCENE is displayed. Alarm state the PREHRIATA TRYSKA is displayed together with the EMERGENCY STOP status and the machine is switched off to prevent damage. The red message VYSOKA TEPLOTA shows us a critical exceedance of normal temperature. The yellow message NÍZKA TEPLOTA it shows us when the nozzle temperature drops below the normal temperature, since it is yellow in color, no intervention is required since the machine automatically calibrates the temperature to normal.

Input area

On the Figure 11 we can see the working area of HMI. In this section, it is possible to switch between modes (Výroba struny / Odlievanie výrobkov - not yet implemented), choose material (ABS / PLA) from which the filament will be produced and the weight of the produced coil (Vaha cievky) and the final number of spools (Pocet cievok). There are control buttons in the right part of this area. The green START button turns on the string production process. Press the red STOP button to stop the production process. The production process can be paused by pressing the cyan POZASTAVIT button and then pressing the cyan POKRACUJ button to continue the production process. The E-STOP button is used to completely shut down the production process in the event of an unexpected error. Below this buttons are buttons that can simulate certain fault conditions during program run. Pressing the Vyprazdnit zásobnik button clears the hopper contents and stops the production process and pauses until the hopper is manually filled. Pressing the Vysoka teplota button will cause the normal nozzle temperature to be exceeded. The Nizka teplota button will manually set the temperature below normal and the program will automatic to adjust the right nozzle temperature. If you press the Prehriata tryska button, the production process stops and switches to EMERGENCY STOP mode.

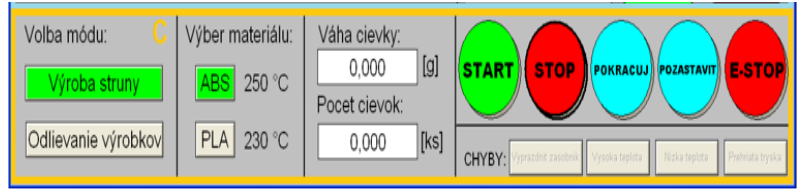

Figure 11 - Input area

DESCRIPTION OF PROGRAM FUNCTION IN HMI. After successfully logging in and selecting the mode, it is necessary to set individual parameters for production. In the overview area (Figure 12), we will display the selected mode, for example, VÝROBA STRUNY together with the date and time, and the UKONCIT and ODHLASIT buttons.

\section{VÝROBA STRUNY UKONCT ODHLAST 12110/2017 3:58:28 PM}

Figure 12 - Overview area

In the working area, it is possible to see the initial state of the manufacturing process where a string making machine is shown together with an engine that is used to wind the manufactured coil with a plastic filament (Figure 13).

In the input area, it is necessary to select the correct mode by starting the production process, select the type of plastic material from which the filament will be produced (Figure 14). 


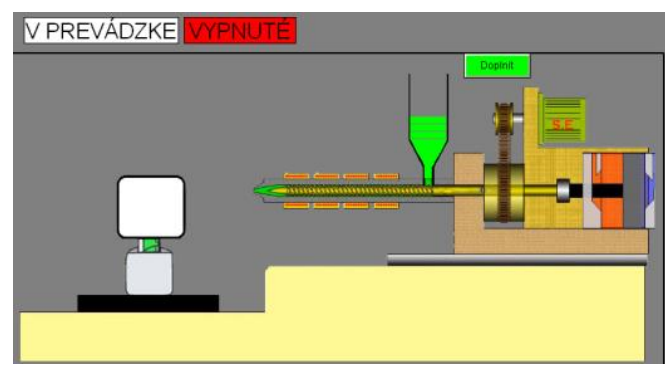

Figure 13 - Working area - device status and technology process

\begin{tabular}{|c|c|}
\hline Volba módu: & \multicolumn{2}{|l|}{ Výber materiálu: } \\
\hline Výroba struny & ABS $250^{\circ} \mathrm{C}$ \\
\hline Odlievanie výrobkov & PLA $230^{\circ} \mathrm{C}$ \\
\hline
\end{tabular}

Figure 14 - Input area - selecting mode and material

Then we need to enter the weight of one coil in grams and the number of coils that we require to produce in pieces. These parameters can no longer be changed when the button is pressed (Figure 15).

\begin{tabular}{l}
$\left.\begin{array}{l}\hline \text { Váha cievky: } \\
\hline 0,000 \\
\text { [g] } \\
\text { Pocet cievok: } \\
\hline 0,000 \\
\hline\end{array}\right]$ [ks] \\
\hline
\end{tabular}

Figure 15 - Input Area - Spool weight and number of spools

It is important to check the condition of the plastic pellets in the hopper as production cannot be started with the empty hopper. If the tray is empty, it is signaled by a blue color alarm in the work area on the right and a red blink of the Doplint button itself. It is necessary to add the required amount of plastic using the Doplnit button next to the hopper (see Figure 16) (one press of the button adds 100 grams of plastic to the hopper, maximum 500 grams can be added). When the tray is empty, the machine is paused. After adding plastic pellets to the hopper it is necessary to press the POKRACUJ button. Then the machine will continue to manufacture plastic filaments.

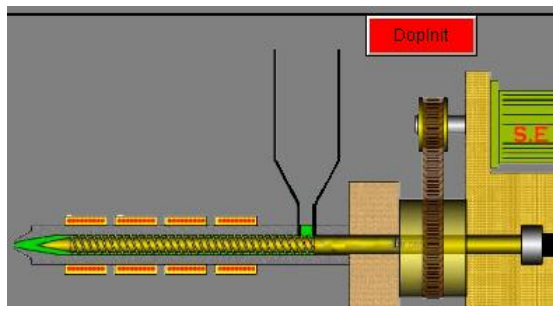

Figure 16 - Empty hopper with red flashing button

Then we can press the START button to start the filament production process. In the working area (see Figure 17) we can notice the change of state from VYPNUTÉ (red color) to the state V PREVÁDZKE (green color).

\section{VPREVÁDZKE VYPNUTÉ}

Figure 17 - Change status from VYPNUTÉ to V PREVÁDZKE

The nozzle temperature gradually starts to rise, which can be seen on the analog display called TRYSKA (Figure 18). The individual temperature readings are explained in the controlling program (in previous publications) for PLA and ABS. As the temperature increases, we can observe the display of the OHREV message indicating the heating of the nozzle to the desired temperature (Figure 18).

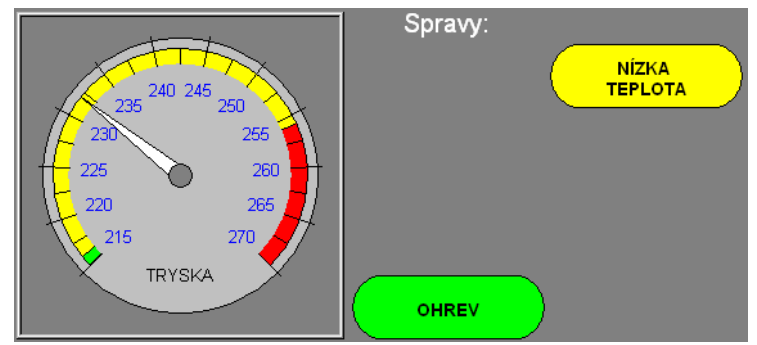

Figure 18 - Displaying the analog temperature TRYSKA and messages OHREV and NÍZKA TEPLOTA

When the desired temperature is reached, the VYTLACANIE message will be displayed to indicate that the filament extrusion process has started and we can also see it at the same time changing the image to the left. After two seconds of the extrusion process starts the winding process, which is indicated by the NAVIJANIE message together with the image change, where we can notice that a certain amount of material has already been wound on the spool (Figure 19).

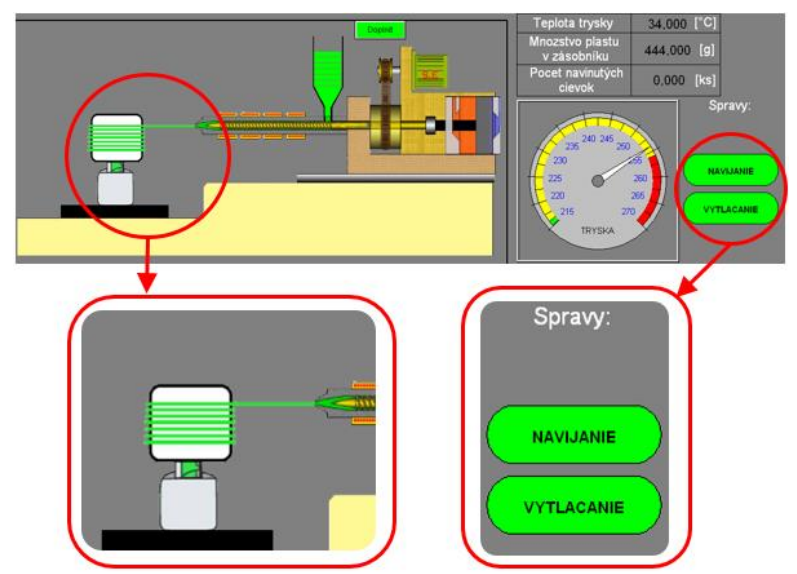

Figure 19 - Messages called VYTLACANIE and NAVIJANIE

Individual messages are displayed cyclically until the required number of entered spools has been produced. When the specified amount of spools is reached, the message DOKONCENE is displayed and the process is terminated (Figure 20). 


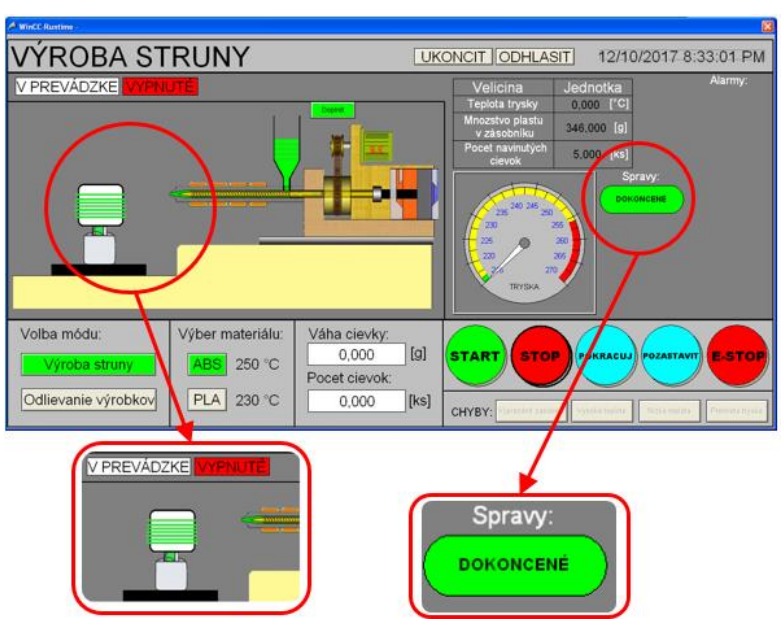

Figure 20 - Exiting the production cycle and displaying the message DOKONCENE

During the production process, errors can be simulated manually using the buttons located in the input area at the bottom right (Figure 21).

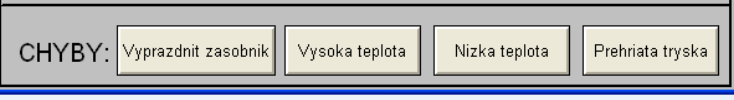

Figure 21 - Buttons for manual error simulation

By pressing the Vyprazdnit zasobnik button we can empty the contents of the hopper to get to when the alarm will be lit PRAZDNY ZASOBNIK DOPLNIT! Next, we can press the Vysoka teplota button to stop plastic extrusion, the extrusion will be suspended until the temperature drops to the working temperature for the plastic used. After achieved the desired temperature, the work cycle is resumed. The Nízka teplota button pauses the plastic extrusion, the heating is switched on to set the desired nozzle temperature. After achieved the desired temperature, the work cycle is resumed. When you press the Prehriata tryska button, the PREHRIATA TRYSKA alarm is displayed, and the device switches to EMERGENCY STOP mode to prevent damage.

CONCLUSION. This paper describes the functionality of a control program for a machine for the production of a plastic filament for a $3 \mathrm{D}$ printer or also called filament extruder. The control program was written in the SIMATIC STEP 7 development environment from SIEMENS. Next aim of this paper was to design and implement an HMI interface for filament extruder. After defining the basic concept of the device, we created the HMI using by SIMATIC WinCC software. The interconnection of the control software of the PLC and the HMI interface was realized without any major difficulties. After the project implementation, we tested the system's functionality. We can say the system works correctly. After appropriate modification and configuration, it could be applied to the physical device for which the project was designed. The hardware part of this device has not yet been realized but will be implemented in the future. Subsequent production of such device would benefit our further research. We could produce different kinds of materials such as composite conductive materials and others.

\section{REFERENCES}

1. Bolton, William (2015). Programmable logic controllers. Newnes.

2. 6 Best Filament Extruders to Build or Buy. All3dp.com. Retrieved from https://all3dp.com/2/6-bestfilament-extruders-to-build-or-buy

3. New modular winder from brabender professionally rounds off laboratory extrusion lines for filament development. 3dprintingindustry.com. Retrieved from https://3dprintingindustry.com/news /new-modular-winder-from-brabender-professionallyrounds -off-laboratory-extrusion-lines-for-filamentdevelopment-138556/

4. How to make DIY Filament for your 3D Printer. 3Dprintingforbeginners.com. Retrieved from http://3dprintingforbeginners.com/h ow-to-make-diyfilament-for-your-3d-printer

5. Plastics extrusion presses. Worksafe.govt.nz. Retrieved from https://worksafe.govt.nz/ topic-andindustry/machinery/working-safely-with-plasticproduction-machinery/plastics-extrusion-presses

6. SIMATIC Programming with STEP 7 Manual. Siemens.com. Retrieved from https://cache.industry.siemens.com/dl/files/056/1865205 6/att_70829/v1/S7prv54_e.pdf

7. What is HMI? Inductiveautomation.com. Retrieved from https://www.inductive automation.com/resources/article/what-is-hmi

8. SIMATIC HMI WinCC V7.2 Getting Started. Siemens.com. Retrieved from https://cache.industry.siemens.com/dl/files/ 596/73505596/att_77660/v1/GettingStarted_en-US.pdf

9. Siemens SIMATIC WinCC Programming. Dmcinfo.com. Retrieved from https://www.dmcinfo.com/services/manufacturingautomation-and-intelligence/hmi-and-scadaprogramming/siemens-simatic-wincc-programming

10. SIMATIC Programming with STEP 7 Manual. Siemens.com. Retrieved from https://cache.industry.siemens.com/ dl/files /056/18652056/att_70829/v1/S7prv54_e.pdf

\section{УСТРОЙСТВО ДЛЯ ИЗГОТОВЛЕНИЯ ПЛАСТИКОВЫХ НИТЕЙ ДЛЯ ЗD ПРИНТЕРОВ}

\section{Я. Мольнар, П. Грабовский}

Технический университет Кошице

ул. Летня, 9, г. Кошице, 04200, Словакия. E-mail: jan.molnar@tuke.sk, peter.hrabovsky@tuke.sk

Целью работы является разработка малобюджетного устройства по производству пластиковых нитей для 3D 
принтера из пластиковых отходов. В статье приведены результаты исследований по разработке малобюджетного экземпляра устройства по производству пластиковых нитей для $3 \mathrm{D}$ принтера с использованием современной элементной базы устройств систем автоматизации. В статье предлагается использовать одну из возможностей разработки малобюджетного устройства по производству пластиковых нитей для 3D принтера под управлением промышленного ПЛК, оборудованного средствами человекомашинного интерфейса. Приведено описание всего производственного процесса, начиная с описания принципов работы устройства, процесса разработки и тестирования управляющего программного обеспечения, и заканчивая разработкой человеко-машинного интерфейса, тестированием и экспериментальной проверкой разработанных программных решений и полученных результатов. Были определены основные концепции построения устройства. Управляющая программа была разработана с использованием среды SIMATIC STEP 7 фирмы SIEMENS. Человеко-машинный интерфейс устройства был разработан с помощью программного обеспечения SIMATIC WinCC. Тестирование взаимодействия управляющего программного обеспечения ПЛК и человеко-машинного интерфейса показало удовлетворительные результаты. После реализации проекта было проверено функциональность системы, что также показало удовлетворительные результаты. После соответствующей модификации и конфигурации, разработанные программные и технические решения могут быть применены в реальном физическом устройстве, для которого и был создан проект. В конечном итоге, будет разработан малобюджетный экземпляр устройства по производству пластиковых нитей для 3D принтера, который позволит поставлять расходный материал для 3D принтеров, что сможет обеспечить собственные нужды. Разработанное устройство позволит производить различные виды материалов, такие как композитные проводящие материалы и другие.

Ключевые слова: управляющая программа, человеко-машинный интерфейс, пластиковые нити, программируемый логический контроллер.

Стаття надійшла 23.08.2019. 